\title{
Nutritional Composition, Physical Characteristics and Sanitary Quality of the Tomato Variety Mongol F1 from Burkina Faso
}

\author{
Edwige B. Oboulbiga1,2, Charles Parkouda1 ${ }^{*}$, Hagrétou Sawadogo-Lingani1 ${ }^{1}$, Ella W. R. Compaoré2, \\ Abdoul Karim Sakira ${ }^{3}$, Alfred S. Traoré2 \\ ${ }^{1}$ Département Technologie Alimentaire, Institut de Recherche en Sciences Appliquées et Technologies, Centre National de la \\ Recherche Scientifique et Technologique, Ouagadougou, Burkina Faso \\ ${ }^{2}$ Centre de Recherche en Sciences Biologique, Alimentaire et Nutritionnelle (CRSBAN), Université Ouaga 1 Pr Joseph KI-ZERBO, \\ Ouagadougou, Burkina Faso \\ ${ }^{3}$ Université Ouaga 1 Pr Joseph KI-ZERBO, Ouagadougou, Burkina Faso \\ Email: *cparkouda@yahoo.fr
}

How to cite this paper: Oboulbiga, E.B., Parkouda, C., Sawadogo-Lingani, H., Compaoré, E.W.R., Sakira, A.K. and Traoré, A.S. (2017) Nutritional Composition, Physical Characteristics and Sanitary Quality of the Tomato Variety Mongol F1 from Burkina Faso. Food and Nutrition Sciences, 8 , 444-455.

https://doi.org/10.4236/fns.2017.84030

Received: March 10, 2017

Accepted: April 24, 2017

Published: April 27, 2017

Copyright (c) 2017 by authors and Scientific Research Publishing Inc. This work is licensed under the Creative Commons Attribution International License (CC BY 4.0).

http://creativecommons.org/licenses/by/4.0/

\section{(c) () Open Access}

\begin{abstract}
Tomato (Lycopersicon esculentum Mill) is quantitatively the highest vegetable consumed in Burkina Faso. The objective of this study was to evaluate the physico-chemical, nutritional characteristics, and sanitary quality of the tomato variety Mongal F1 from different production sites. Twenty-eight (28) samples of Mongal F1 fresh tomatoes were collected from 28 producers at three different localities of Ouahigouya, Loumbila and Ouagadougou. The physico-chemical and nutritional characteristics were determined by standardized methods and the traces metallic elements by atomic absorption spectrophotometry. The results revealed a degree brix varying from $4.07^{\circ}$ to $5.50^{\circ}$ and a $\mathrm{pH}$ ranging from 3.71 to 4.08 corresponding to a total acidity of $0.39 \%$ to $0.55 \%$ citric acid equivalents. The moisture content, the ash content, the total carbohydrates content, the reducing carbohydrates content, the lipids content and the protein content were ranged from $95.09 \%$ to $96.17 \%, 9.25 \%$ to $10.60 \%, 47.00 \%$ to $53.43 \%$, $30.03 \%$ to $41.21 \%, 3.04 \%$ to $7.71 \%$ and $17.09 \%$ to $25.03 \%$ respectively. The results of the trace metals showed a high accumulation of total cadmium from 0.11 to $0.22 \mathrm{ppm}$, of total lead of 1.15 to $1.27 \mathrm{ppm}$ and arsenic total of 0.19 to $0.20 \mathrm{ppm}$. The results proved that environmental conditions influence the quality of the tomato Mongal F1. Detection of trace elements in the tomato fruits suggests that a better production practices are needed.
\end{abstract}

\section{Keywords}

Tomato, Mongol F1, Characteristics, Nutrient, Trace Metal 


\section{Introduction}

Fruits and vegetables are an excellent source of nutrients for the human diet but in several developing countries their availability is seasonal. Tomato (Lycopersicum esculentum Mill.) is one of the most cultivated fruit vegetable consumed in the world in fresh or processed form [1]. In Burkina Faso, tomato occupies a very important place in the vegetable sector (second after onion) with a 157,067 metric tons in 2008 and 179,217 metric tons in 2011 [2].

Tomato has high content of water, minerals ( $\mathrm{Ca}, \mathrm{Fe}, \mathrm{K}, \mathrm{Mg}, \mathrm{Na}$ ) and vitamins including pro-vitamin A, vitamin C and B vitamins [3] [4] [5]. It is also rich in antioxidant such as total phenolics, flavonoids, lycopene, and ascorbic acid [6]. The nutritional composition of tomato may vary depending on several factors such as variety, cultivation techniques, the locality and the sampling period [4]. On the health concern, tomato like other vegetables may accumulate metal micropollutants in the heart of their culture [7] [8] [9]. These accumulations can sometimes exceed the recommended standards [8] [10] and induce health problems for the human body [11] [12].

In Burkina Faso, tomato is produced by small holding farmers during the rainy and dry season. Several tomatoes cultivars are grown but varieties such as "Roma Vf”, “Rossol Vfn”, “Caraibo”, “Xina”, "Mongal F1", "Petomech”, “Tropimech", "Red Cloud Vf", "Nadira", "Jaguar", and "F1 Thorgal" are preferred [13]. Despite the importance of the tomato fruit in Burkina Faso, to date very few published studies were done on the nutritional and health characteristics of tomato in Burkina Faso. Most of the researches done are oriented to agronomy practices [14]. Therefore the aim of the present study was to determine the morphological and physicochemical characteristics, the nutritional composition and the levels of trace metals of tomato Mongal F1 for technological and nutritional interest.

\section{Material and Methods}

\subsection{Sampling}

Twenty-eight (28) samples of fresh tomatoes (variety Mongal F1) were collected from three production sites including Loumbila, Ouahigouya and Ouagadougou. Twelve (12) samples were collected in Loumbila, thirteen (13) in Ouahigouya and three (3) in Ouagadougou (research experimental site at IRSAT). At each production site randomly selected, about 120 tomato fruits were randomly picked from different batches to constitute a sample. Fresh tomatoes from the same batch were weighed, washed with distilled water, drained and mashed. The mashed samples were homogenized and divided into two parts packed (with plastic opaque bottle) and stored in a freezer at $-20^{\circ} \mathrm{C}$ for analysis.

\subsection{Analytical Method of Morphological Characteristics}

The height and the diameter of the tomato were measured using a digital caliper. The shape coefficient (Cf) was determined as described by Doussou et al. [15]: 
$\mathrm{Cf}=$ Height/Diameter. The firmness, the color and the green collar were determined according to by the method used by Fagbohoun and Kiki [16]; firmness was appreciated by touch (finger pressure) whilst color and green collar were visually appreciated. The number of lobs was determined by the method of counting the cross-section of tomato [16]. The average weight of the fruit, the average content of pulp, the average content of epicarp and the average content of seeds were determined by measurement carried out using an electronic balance [16]. The weight and average contents of the samples were obtained on the basis of 40 tomatoes.

\subsection{Determination of Physicochemical Characteristics}

Acidity and $\mathrm{pH}$ were determined according to AFNOR [17]. About $5 \mathrm{~g}$ of sample are suspended in $25 \mathrm{ml}$ of distilled water. After a strong magnetic stirring, the $\mathrm{pH}$ is measured using a $\mathrm{pH}$ meter previously calibrated. For the acidity determination, the solution is centrifuged at $5000 \mathrm{~g}$ for $5 \mathrm{~min}$; the collected supernatant was then titrated with $0.1 \mathrm{M} \mathrm{NaOH}$ in presence of a few drops of phenolphthalein and the content was calculated as percentage of citric acid. The degree brix was measured directly with a refractometer according to the NF V05-109 [18].

\subsection{Determination of Nutritional Characteristics}

Moisture content, ash content, crude protein content and crude fat content were determined according to the AOAC official methods [19]. samples moisture content was determined by drying in an oven at $105^{\circ} \mathrm{C}$ overnight, total ash was determined by the difference of weight before and after incineration at $600^{\circ} \mathrm{C}$ overnight, total proteins were determined by the Kjeldahl method and crude fat content was determined using Soxhlet method with hexane as solvent. The total sugars were determined according to the sulfuric orcinol methods as described by Montreuil and Spik [20]. The reducing sugars were determined by the sodium Dinitrosalycilate (DNS) method. The theoretical energy value was calculated using the coefficients of Merrill and Watt [21].

\subsection{Analytical Method of Metallic Trace Elements}

The metallic trace elements were determined by Atomic Absorption Spectrophotometry (AAS) as described by Walsh (1955) [22]. Cadmium and Lead were analysed by Atomic Absorption Spectrophotometry flame. Arsenic was determined by Atomic Absorption Spectrophotometry flame after generating volatile hydrides. Mercury was determined by AAS after generating cold steam hydrides.

Determination of Cadmium and Lead contents: The samples are first treated by acid digestion $0.2 \mathrm{~g}$ (of samples) is introduced into a glass vial and 10 $\mathrm{mL}$ of concentrated nitric acid are added thereto. The whole is left at laboratory temperature for 24 hours. The mineral deposit obtained is diluted 1/100 with Milli Q water and used for the determination of the cadmium and lead contents by the spectrophotometric method. Their dosage in the different samples re- 
quired a first calibration step of the apparatus. For calibration purposes, a series of standard cadmium solution on the one hand and the lead on the other hand are prepared from commercial stock solutions dosed at $1000 \mathrm{ppm}$. Preparation of the calibration range of $0.2 ; 0.4 ; 0.6 ; 0.8$ and $1 \mathrm{~g} / \mathrm{ml}$ was the introduction of 20 , $40,60,80$, and $100 \mu \mathrm{l}$ of a part in the solution of cadmium and secondly the Lead solution in $100 \mathrm{ml}$ flasks. Then $1 \%$ of $0.5 \mathrm{~N}$ nitric acid is added thereto, the remaining volume is made up with Milli-Q water. Before the establishment of the calibration curve with the SpectrAA software (Pro version 1.5), the camera sensitivity is first verified. For this, certain parameters such as the quality of the light beam and flame quality are optimized to achieve the best possible signal. Furthermore, a blank made from the same matrix as the sample (Milli-Q water acidified) and a known concentration of control solution are used and treated in the same way as the samples. The results were given by the SpectrAA software (Pro 1.5) and expressed in ppm.

Determination of Mercury: The samples are first treated by acid digestion. $0.2 \mathrm{~g}$ of sample is introduced into a glass vial and $10 \mathrm{~mL}$ of concentrated nitric acid are added thereto. The whole is left at ambient temperature for 24 hours. The methodology used is based on hydrides generation. For calibration purposes, series of standard solutions of cadmium on hand and lead on the other are prepared from commercial stock solutions dosed at 1000 ppm. All these standard solutions are handled as samples, that is to say dilution performed with acidified Milli-Q water. Working solutions obtained were concentrated to 20, 40, 60 and $80 \mathrm{ppb}$. The reagents necessary for the hydrides generation are also prepared: in this case, a reducing solution of sodium borohydride $\left(\mathrm{NaBH}_{4} 0.5 \%\right)$, stabilized with sodium hydroxide $(\mathrm{NaOH} 0.5 \%)$ and a solution of hydrochloric acid ( $5 \mathrm{M} \mathrm{HCl}$ ). Before the establishment of the calibration curve, the camera sensitivity is first checked. For this, certain parameters are optimized to achieve the best signal possible. Furthermore, control solutions, including a blank made from the same matrix as the sample (Acidified Milli-Q water) and a reference material are used and treated in the same way as the samples. The results were given by the SpectrAA software (Pro 1.5) and expressed in ppm. The concentration is calculated according to the test sample and the dilution of the mineral deposit.

Determination of Arsenic: The samples are first treated by acid digestion. Thus, $0.2 \mathrm{~g}$ of sample is introduced into a glass vial and $10 \mathrm{~mL}$ of concentrated nitric acid are added thereto. The whole is left at ambient temperature for 24 hours. They are then placed in an oven at $50^{\circ} \mathrm{C}$ for $30 \mathrm{~min}$ to reduce pentavalent species by a reducer (KI + Vitamin C). The methodology use dis based on hydrides generation. The determination of arsenic in different matrices needs first a calibration step of the apparatus. For calibration purposes sseries of arsenic standard solution are prepared from the commercial stock solution dosed at $1000 \mathrm{ppm}$. These standard solutions are all treated as the samples that is to say dilution performed with water (Milli-Q) and acidified reduction with potassium iodide solution and vitamin C. Working solutions obtained are concentrated to 
5, 10 and $15 \mathrm{ppb}$. The reagents necessary for the hydrides generation are also prepared: in this case, a reducing solution of sodium borohydride $\left(\mathrm{NaBH}_{4} 0.5 \%\right)$, stabilized with sodium hydroxide $(\mathrm{NaOH} 0.5 \%)$ and a solution of hydrochloric acid $(5 \mathrm{M} \mathrm{HCl})$. Before the establishment of the calibration curve, the camera sensitivity is first checked. For this, certain parameters are optimized to achieve the best signal possible. Furthermore, control solutions, including a blank made from the same matrix as the sample (acidified Milli-Q water) and a reference material are used and treated in the same way as the samples. The results were given by the SpectrAA software (Pro 1.5) and expressed in ppb (ug/L). The concentration is calculated according to the test sample and the dilution of the mineral deposit.

\subsection{Statistical Analysis}

The data were subjected to Principal Component Analysis (PCA) and to analysis of variance (ANOVA) using the XLSTAT software (Ver.2014.5.03). Differences between means were evaluated by Duncan's test. Statistical significant difference was stated at $\mathrm{P}<0.05$.

\section{Results and Discussion}

The morphological characteristics of the tomato Mongal F1 are shown in Table 1. The fruits from Loumbila had a shape coefficient of $0.75 \pm 0.15$ corresponding to a flattened and ribbed shape and those from Ouahigouya and Ouagadougou had a shape coefficient of respectively $0.88 \pm 0.15$ and $0.82 \pm 0.6$ with a round shape. The shape difference between samples may be due to mixing this variety with others for hybridization of this variety with other varieties since on a same field several varieties may be cultivated [16]. All samples had a very soft firmness, red color and the number of lobs ranging from 3 to 14 . With a very soft firmness this variety maybe less prone to room temperature storage and transportation. The observed color is close to the red color described by Namestnikov [23]. This variety may be interesting for the consumers as Namestnikov [23] reported that the dark red and red are the preferred colors of consumers. The average weight was between $58.70 \pm 9.65$ and $72.49 \pm 0.46 \mathrm{~g}$.

Table 1. Morphological characteristics of tomato Mongal F1.

\begin{tabular}{|c|c|c|c|c|c|c|c|}
\hline \multicolumn{8}{|c|}{ Parameters } \\
\hline Localities & Shape coefficient & Form & Firmness & Color & $\begin{array}{l}\text { Green } \\
\text { collar }\end{array}$ & $\begin{array}{c}\text { Number of } \\
\text { lobs }\end{array}$ & Average weight (g) \\
\hline Loumbila & $0.75 \pm 0.15$ & Flattened and ribbed & Solf & Red & Rare & $3-9$ & $58.70 \pm 9.65^{\mathrm{b}}$ \\
\hline Ouahigouya & $0.88 \pm 0.12$ & Round & Solf & Red & Rare & $3-14$ & $76.55 \pm 20.4^{\mathrm{a}}$ \\
\hline $\mathrm{p}$ value & & & & & & & 0.012 \\
\hline Signification & & & & & & & * \\
\hline
\end{tabular}

Mean values in the same column with the same superscript letters are not significantly different at $\mathrm{P}<0.05 ;{ }^{\star} \mathrm{P}<0.01$. 
Table 2. Physicochemical characteristics of tomato F1 Mongal.

\begin{tabular}{cccc}
\hline \multirow{2}{*}{ Localities } & \multicolumn{3}{c}{ Parameters } \\
\cline { 2 - 4 } & $\mathrm{pH}$ & Acidity $(\%$ citric acid équivalent $)$ & Degree brix $\left({ }^{\circ}\right.$ Brix $)$ \\
\hline Loumbila & $3.71 \pm 0.05^{\mathrm{b}}$ & $0.55 \pm 0.03^{\mathrm{a}}$ & $5.51 \pm 0.43^{\mathrm{a}}$ \\
Ouahigouya & $3.71 \pm 0.05^{\mathrm{b}}$ & $0.50 \pm 0.05^{\mathrm{a}}$ & $5.02 \pm 0.59^{\mathrm{b}}$ \\
Ouagadougou & $4.08 \pm 0.05^{\mathrm{a}}$ & $0.39 \pm 0.05^{\mathrm{b}}$ & $4.07 \pm 0.61^{\mathrm{c}}$ \\
p value & 0.0001 & 0.000 & 0.000 \\
Signification & $* * *$ & $* * *$ & $* .86 \pm 0.73$ \\
Average & $3.93 \pm 0.19$ & $0.48 \pm 0.08$ & 4.00 \\
\hline
\end{tabular}

Tests were performed in triplicate; Values are means \pm Standard Deviation. Mean values in the same column with the different superscript letters are significantly different at $\mathrm{P}<0.05$; ${ }^{* *} \mathrm{P}<0.001$.

The physicochemical characteristics of tomato Mongal F1 from the different sites are presented in Table 2. The $\mathrm{pH}$ was ranged between $3.71 \pm 0.05$ and 4.08 \pm 0.05 corresponding to a total acidity of $0.39 \% \pm 0.05 \%$ to $0.55 \% \pm 0.03 \%$. For the total acidity, a significant difference was observed among the three tomatoes sampling sites $(\mathrm{P}<0.05)$. The $\mathrm{pH}$ found are in line with those obtained by Fagbohoun and Kiki [16] and Dossou et al. [15] who found values from 3.7 to 4.1 and 4.01 to 4.17 respectively. In contrary, these values are lower than those obtained by Aoun et al. [24] who reported values between 4.19 and 4.45 for 16 tomato varieties collected from Tunisia. Previous studies reported that $\mathrm{pH}$ of 3 to 6 is very favorable to the growth of yeasts and molds while bacteria prefer neutral media, typically pH between 7 and 9 [25]. The Mongal $\mathrm{F} 1$ tomato can be ranked among the acidic food category $(3<\mathrm{pH}<6)$ meaning that the products from this variety are not favorite media for the growth of some pathogens. The total acidity is similar to those obtained by Fagbohoun and Kiki [16] and Dossou et al. [15] with respective values from $0.48 \%$ to $0.6 \%$ and from $0.26 \%$ to $0.45 \%$. According to Saliba [26], acidity may be influenced by temperature. The degree brix ranged from 4.07 to 5.50 with a significant difference among the three sampling sites. The degree brix obtained for this variety is superior to that found by Aoun et al. [24] who reported values ranging from 2.02 to 4.57 for 16 varieties of traditional tomatoes from Tunisia. The values found were similar to those found by Fagbohoun and Kiki [16] who reported values ranging from 4.2 to 5.1.

The proximate composition of the tomato fruits is shown in Table 3. The water content ranged from $95.09 \%$ to $96.17 \%$ with a significant difference between tomatoes from Loumbila and the other two sites. The values obtained are higher than those of FAO [5] and Sulbarán et al. [27] who reported value of $93.5 \%$ and $94.60 \%$ respectively. This difference may be due to the variety and cultivation conditions such as water supply. These values found shows that tomato is one of the vegetables with high water content, which explains its perishable nature, limiting the suitability for room temperature storage for a long period of time [28]. Crude ash content was ranged from $9.25 \%$ to $10.60 \%$. There was no significant difference between the different sampling sites. Dossou et al. [15] and Hernández et al. (2008) [4] found in other varieties values ranging respectively 
Table 3. Nutritional composition of the tomato Mongal F1.

\begin{tabular}{|c|c|c|c|c|c|c|c|}
\hline & \multicolumn{7}{|c|}{ Parameters } \\
\hline Localities & Moisture (\%) & Ash (\% DM) & $\begin{array}{l}\text { Total sugar } \\
(\% \mathrm{DM})\end{array}$ & $\begin{array}{l}\text { Reducing sugars } \\
\quad(\% \mathrm{DM})\end{array}$ & Lipid (\% DM) & Protein (\% DM) & $\begin{array}{c}\text { Energy } \\
\text { (Kcal/100g DM) }\end{array}$ \\
\hline Loumbila & $95.09 \pm 0.47^{\mathrm{b}}$ & $9.79 \pm 1.32^{\mathrm{a}}$ & $47.00 \pm 6.29^{\mathrm{a}}$ & $30.03 \pm 7.82^{\mathrm{b}}$ & $4.77 \pm 1.21^{\mathrm{b}}$ & $25.03 \pm 3.17^{\mathrm{a}}$ & 331.05 \\
\hline Ouahigouya & $9568 \pm 0.63^{\mathrm{a}}$ & $10.60 \pm 0.32^{\mathrm{a}}$ & $\begin{array}{r}48.29 \\
\pm 6.52^{\mathrm{a}}\end{array}$ & $36.27 \pm 7.99^{\mathrm{ab}}$ & $5.39 \pm 1.25^{\mathrm{ab}}$ & $24.36 \pm 3.78^{\mathrm{a}}$ & 339.11 \\
\hline Ouagadougou & $96.17 \pm 0.61^{\mathrm{a}}$ & $9.25 \pm 1.59^{\mathrm{a}}$ & $53.43 \pm 6.95^{\mathrm{a}}$ & $41.21 \pm 8.08^{\mathrm{a}}$ & $7.00 \pm 1.26^{\mathrm{a}}$ & $17.09 \pm 0.02^{\mathrm{a}}$ & 345.08 \\
\hline$P$ value & 0.006 & 0.236 & 0.385 & 0.055 & 0.034 & 0.137 & 0.52 \\
\hline Signification & $* *$ & NS & NS & * & * & NS & \\
\hline Average & $95.64 \pm 0.54$ & $9.88 \pm 0.67$ & $49.57 \pm 3.40$ & $35.83 \pm 5.60$ & $5.72 \pm 1.15$ & $22.16 \pm 4.40$ & $338.41 \pm 7.04$ \\
\hline
\end{tabular}

Tests were performed in triplicate; Values are means \pm Standard Deviation, DM: Dry Matter, Mean values in the same column with different superscript letters are significantly different at $\mathrm{P}<0.05$; NS non-significant; ${ }^{\star} \mathrm{P}<0.05 ;{ }^{\star *} \mathrm{P}<0.01$.

from $4.94 \%$ to $10.74 \%$, and $9.84 \%$ to $10.48 \%$. Similarly, Agassounon et al. [28] found a value of $11.2 \%$. According to Ahishakiye and Ait [29], the variability of the ash content can be influenced by the culture methods such as the use intake of organic and mineral fertilizers during the production and the type of soil: organic and mineral compositions

The total sugar and reducing sugars contents ranged respectively from $47.00 \%$ to $53.43 \%$ and from $30.03 \%$ to $41.21 \%$. Tomatoes from Loumbila showed the lowest values and those from Ouagadougou the highest. There was no significant difference between the tomatoes content in total carbohydrate whilst a significant difference were noted for reducing sugars between tomatoes from Loumbila and Ouagadougou. The total sugar content of the tomatoes were lower than those found by Dossou et al. [15] on other tomato varieties with values ranging from $53.48 \%$ to $88.17 \%$. In terms of reducing sugars, the values are lower than those obtained by Dandjouma et al. [3], Dossou et al. [15], Agassounon et al. [28] on other tomato varieties with respective values of $53.63 \%$ to $56.33 \%, 69.8 \%$ and $40.35 \%$ to $78.86 \%$. This difference in sugar content could be due to the varieties and cultivation techniques used. Indeed, according to Davies and Winsor [30], cited by Saliba [26], the plants cultivation techniques, particularly the electrical conductivity of the nutrient solutions, influence the sugar content in fruits. Also Davies and Hobson [30] showed that light has a major effect on the sugar concentration. The protein and fat contents respectively ranged from $17.09 \%$ to $25.03 \%$ and from $4.77 \%$ and $7.00 \%$. There was no significant difference between sampling sites except for the fat where there is a significant difference between tomatoes from Loumbila and Ouagadougou. Values in proteins are higher to those obtained by Hernandez et al. [4], ranging from $12.58 \%$ to $14.03 \%$ on a study of 06 varieties. However, the proteins values found in the present study were similar to those obtained by Korkalo et al. [31] in Mozambique and FAO [5] with respective averages of $15.79 \%$ and $15.38 \%$. As to the fat content the values were superior to those obtained by Korkalo et al. [31] and FAO [5] in Mozambique who reported average values of $3.08 \%$ and $3.51 \%$ respectively. The 
energy values of the samples ranged from 288.20 to $344.24 \mathrm{Kcal} / 100 \mathrm{~g} \mathrm{DM}$. Almost samples were lower in energy than the values (338.46 Kcal/100g DM) reported by FAO [5]. The lower energy value can be explained by the lower content in lipid compared to the content in carbohydrates and protein.

The ACP analysis (Figure 1) shown a total inertia percentage of $100.00 \%$ (86.88\% for F1 and $13.12 \%$ for F2) of the viable results. A good representation of ash, energy and reducing sugars was observed with respect to the main axis F1. With respect to the main axis F2, the total sugars, fat, proteins and water content parameters were more represented. This allowed differentiation between the two axes three groups of individuals. The Ouagadougou samples were slightly close to the lipid axis and even closer to that of total sugars. This is due to their higher sugar content compared to the lipid content. The Ouahigouya samples were mainly characterized by the water, ash and protein content variables and were significantly similar for these variables. They can therefore be considered as having high content in these variables. The samples from Loumbila were distant from all the axes of the variables. They were therefore poor in all nutrients compared to the other samples. The samples of the three localities are far from the energy and total sugars variables. This means that they are poor in these variables.

The contents of total $\mathrm{Cd}$ and total $\mathrm{Pb}$ respectively ranged from 0.11 to 0.22 ppm and 1.15 to $1.27 \mathrm{ppm}$ (Table 4). Total As content was ranged between 0.19 and $0.20 \mathrm{ppm}$. Regarding to total $\mathrm{Hg}$, no value were recorded at the detection

Biplot (axes F1 and F2: 100.00\%)

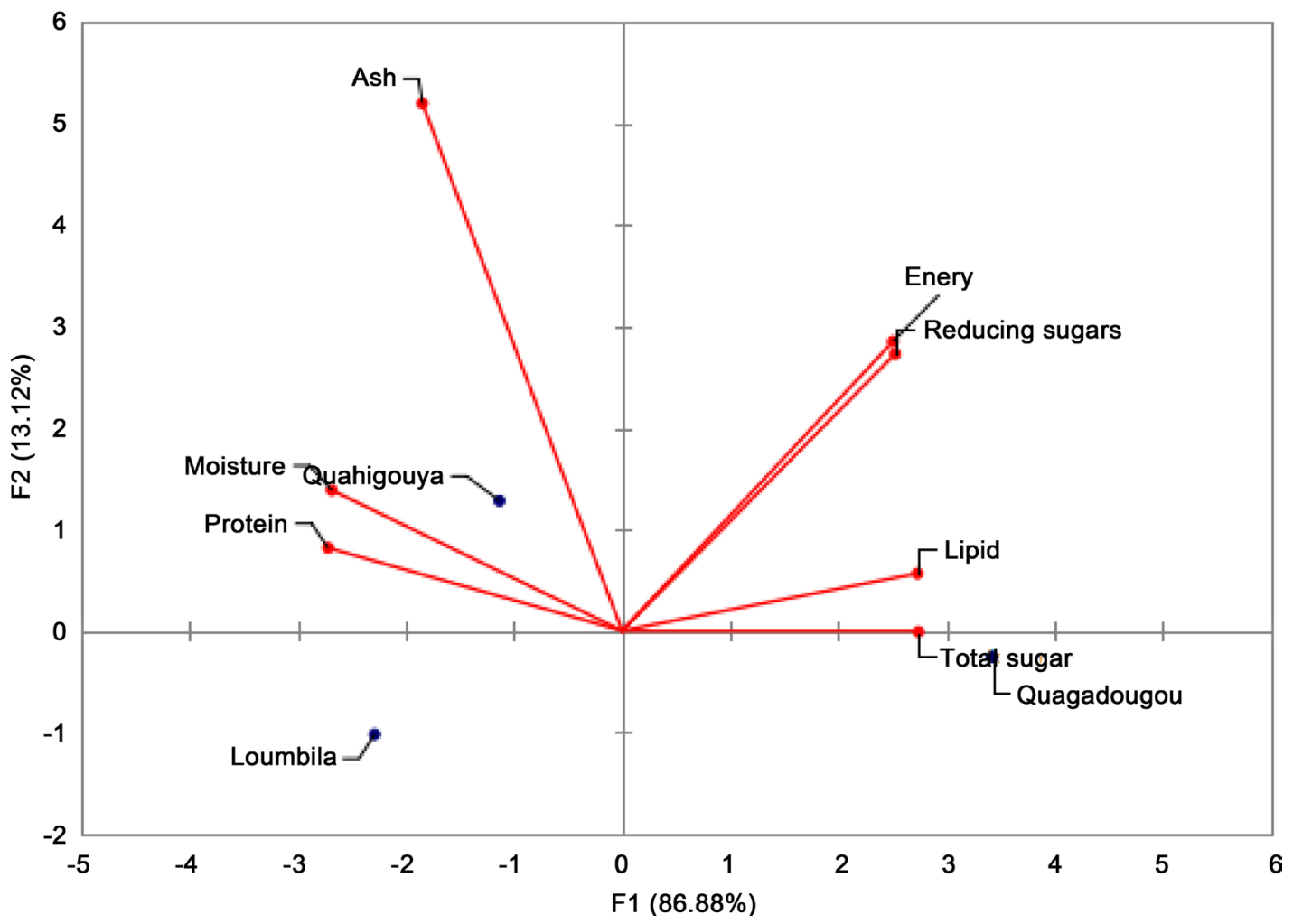

Figure 1. Principal component analysis of nutritional characteristic. 
Table 4. Levels of trace metals Mongal F1 tomato samples.

\begin{tabular}{cccc}
\hline \multirow{2}{*}{ Metalic trace elements } & \multicolumn{3}{c}{ Localities } \\
\cline { 2 - 4 } & Loumbila & Ouahigouya & Codex regulation limit $(\mathrm{ppm})$ \\
\hline Cd total $(\mathrm{ppm})$ & $0.11 \pm 0.00$ & $0.22 \pm 0.28$ & 0.05 \\
$\mathrm{~Pb}$ total $(\mathrm{ppm})$ & $1.27 \pm 0.06$ & $1.15 \pm 0.27$ & 0.1 \\
As total $(\mathrm{ppm})$ & $0.19 \pm 0.14$ & $0.20 \pm 0.02$ & 0.01 \\
Hg total $(\mathrm{ppm})$ & $<\mathrm{LD}$ & $<\mathrm{LD}$ & \\
\hline
\end{tabular}

$\mathrm{LD}=0.001$.

limit of the method used $(0.001 \mathrm{ppm})$. The results shown that there was a large accumulation of total $\mathrm{Cd}$, total $\mathrm{Pb}$ and total As on the studied tomato samples. In general, the levels of the three trace metals was much higher than the values set by Codex Standard [32], which are $0.05 \mathrm{ppm}, 0.1 \mathrm{ppm}$ and $0.01 \mathrm{ppm}$ for the total $\mathrm{Cd}$, total $\mathrm{Pb}$ and total As respectively. The values reported in the present study are higher than normal concentrations typically found in previous studies on vegetables $\left(2,5 \times 10^{-3} \mathrm{ppm}\right)$ cultivated in an unpolluted environment. Similarly, these levels are higher than the results found on tomatoes in other countries on tomatoes: Karavoltsos et al. [33] in Greece reported a total Cd content of $0.0188 \mathrm{ppm}$, Mohamed et al. [34] in Egypt reported $0.01 \mathrm{ppm}$ for total Cd and $0.26 \mathrm{ppm}$ for total $\mathrm{Pb}$. Likewise Guerra et al. [35] in São Paulo in Brazil found a total Cd content of 0.02 to $0.04 \mathrm{ppm}$. Another study reported by Radwan and Salama [36] in Egypt shown a value of $0.01 \mathrm{ppm}$ for total $\mathrm{Pb}$. By contrast, the results found are lower than those found by Parveen et al. [37] in Pakistan with values of $1.33 \mathrm{ppm}$ for total $\mathrm{Cd}$ and $1.56 \mathrm{ppm}$ for total $\mathrm{Pb}$; Kananke et al. [38] with values from 0.18 to 1.59 for total $\mathrm{Pb}$ and Al-Chaarani et al. [39] in Tripoli (Lebanon) with values of 0.17 to $0.82 \mathrm{ppm}$ for total Cd. Trace metals found in tomato samples may originated from environment as soil, water dams, dwells and air [40] and also due to the agricultural activity such as the use of chemical fertilizers, pesticides and household waste [41]. According to Picot [12] some heavy metals such as $\mathrm{Cd}$ accumulated in plants were from agricultural activities such as the supply in phosphate fertilizers rich in $\mathrm{Cd}$ and spreading of sewage sludge in market gardens. According to Miquel [11] and Picot [12], these trace metals when they are highly concentrated are toxic to the human body and can lead to serious disorders, including the brain disorders. By comparing the values with the Codex standards [32], the consumption of this vegetable-fruit could affect the health of consumers, but speciation of these metallic elements is needed since the toxicity of the metal may depend on its chemical form [42].

\section{Conclusion}

Tomato Mongal F1 fruits were found to be good sources of nutritional content. These fruits should be included in the diet to overcome various nutritional problems like minerals deficiencies. The results revealed that environmental conditions influence the quality of the tomato Mongal F1. Even if efforts were made to 
boost the tomato production, yet no action was undertaken to limit the presence of trace metals in tomato fruits. Detection of trace elements in the tomato fruits suggests that better production practices are needed.

\section{Acknowledgements}

The authors are grateful the West African Agricultural Productivity Programme (WAAPP/PPAAO) which funded this work.

\section{References}

[1] Beckles, D.M. (2012) Factors Affecting the Postharvest Soluble Solids and Sugar Content of Tomato (Solanum lycopersicum L.) Fruit. Postharvest Biology and Technology, 63, 129-140.

[2] MASA (2013) Situation de référence des principales filières Agricoles au Burkina Faso. 208 p.

[3] Dandjouma, A.A.K., Kouebou, C., Kameni, A., Tchiegang, C., Yezouma, C. and Desmorieux, H. (2005) Valorisation des légumes tropicaux par le séchage: Etude de quelques conditions de production et conservation de la tomate séchée. $6 \mathrm{p}$.

[4] Hernández Suárez, M., Rodríguez Rodríguez, E.M. and Díaz Romero, C. (2008) Chemical Composition of Tomato (Lycopersicon esculentum) from Tenerife, the Canary Islands. Food Chemistry, 106, 1046-1056.

[5] FAO (2012) West African Food Composition Table; Table de composition des aliments d'Afrique de l'Ouest. Rome, Italie, $148 \mathrm{p}$.

[6] Toor, R.K. and Savage, G.P. (2005) Antioxidant Activity in Different Fractions of Tomatoes. Food Research International, 38, 487-494.

[7] Kassaoui, H., Lebkiri, M., Lebkiri, A., Rifi, E.H., Badoc, A. and Douira, A. (2009) Bioaccumu-lation de métaux lourds chez la tomate et la laitue fertilisées par les boues d'une station d'épuration. Bulletin de la Société de pharmacie de Bordeaux, $148,77-92$.

[8] Omar, I.E.M. (2010) Quantification des résidus de pesticide sur la tomate et le poivron et l'étude de la dégradation de difenoconazole sous l'effet de photooxydants atmosphériques à l'interface solide /gaz. Thèse en Co-tutelle. Université de Reims Champagne-Ardenne l'interf, $160 \mathrm{p}$.

[9] Adu, A.A., Aderinola, O.J. and Kusemiju, V. (2014) Assessment of Trace Metal Levels in Commonly Edible Vegetables from Selected Markets in Lagos State, Nigeria. Current World Environment, 9, 789-796. https://doi.org/10.12944/CWE.9.3.28

[10] Kissao, G., Koffi, T., Aléodjrodo, P.E., Hazou, A. and Koffi, A. (2008) Bioaccumulation de certains éléments métalliques dans les produits maraîchers cultivés sur les sols urbains le long de l'autoroute Lomé-Aného, Sud Togo. Acta Botanica Gallica: Botany Letters, 155, 415-426. https://doi.org/10.1080/12538078.2008.10516121

[11] Miquel, M.G. (2001) Les effets des métaux lourds sur l'environnement et la santé. Rapport Office parlementaire d'évaluation des choix scientifiques et technologiques, $365 \mathrm{p}$.

[12] Picot, A. (2007) Le trio mercure, plomb, cadmium. Les métaux lourds: De grands toxiques. $8 \mathrm{p}$.

[13] INERA (2007) Itinéraire technique de production de la tomate. 2 p.

[14] Dabire, C., Sereme, A., Parkouda, C., Somda, M.K. and Traore, A.S. (2016) Influence of Organic and Mineral Fertilizers on Chemical and Biochemical Compounds 
Content in Tomato (Solanum lycopersicum) var. Mongal f1. Journal of Experimental Biology and Agricultural Sciences, 4, 631-636.

https://doi.org/10.18006/2016.4(Issue6).631.636

[15] Dossou, J., Soulé, I. and Montcho, M. (2007) Evaluation des caractéristiques physico-chimiques et sensorielles de la purée de tomate locale produite à petite échelle au Bénin. Tropicultura, 25, 119-125.

[16] Fagbohoun, O. and Kiki, D. (1999) Aperçu sur les principales variétés de tomate locale cultivées dans le sud du Bénin. Bulletin de la Recherche Agronomique du Bénin, 24, 10-21.

[17] AFNOR (1986) Recueil de normes françaises, produits dérivés des fruits et légumes, jus de fruits. 2ème Edition.

[18] Norme Francaise VO5 109 (1970) Produits dérivés des fruits et légumes-Détermination con-ventionnelle du résidu sec soluble (méthode réfractométrique).

[19] AOAC (2005) Official Methods of Analysis of AOAC International. 18th Edition, AOAC International, Arlington, VA.

[20] Montreuil, J. and Spik, G. (1969) Microdosage des glucides. Méthodes colorimétriques de do-sage des glucides totaux. $85 \mathrm{p}$.

[21] Merill, A. and Watt, B.K. (1995) Energy Value of Foods. Basic and Derivation, 74 p.

[22] Walsh, A. (1955) The Application of Atomic Absorption Spectra to Chemical Analysis. Spectrochim Acta, 7, 108-217. (correction, p. 252)

[23] Namestnikov, A.F. (1973) Qualité de Conserves. 133-162.

[24] Aoun, A.B., Lechiheb, B., Benyahya, L. and Ferchich, A. (2013) Evaluation of Fruit Quality Traits of Traditional Varieties of Tomato (Solanum lycopersicum) Grown in Tunisia. African Journal of Food Science, 7, 350-354. https://doi.org/10.5897/AJFS2013.1067

[25] Bocquet, J. (1982) Généralités sur les microorganismes, Ed Tec et Doc Lavoisier, Paris, 11-46.

[26] Saliba-Colombani, V. (2000) Qualité organoleptique de la tomate: Cartographie de QTL des composantes physiques, chimiques et sensorielles. Thèse de doctorat en Sciences de la vie, Université Paris VI, Paris, France, 146.

[27] Sulbarán, B., Sierra, E., Ojeda de Rodríguez, G., Berradre, M., Fernández, V. and Peña, J. (2011) Evaluación de la actividad antioxidante del tomate crudo y procesado. Revista de La Facultad de Agronomia, 28, 273-291.

[28] Agassounon, M., Tchibozo, D., Gomez, S., Tchobo, F.P. and Soumanou, M.M. (2012) Essai de conservation de la tomate par la technique de la déshydratation imprégnation par immersion (DII). International Journal of Biological and Chemical Sciences, 6, 657-669. http://ajol.info/index.php/ijbcs

[29] Ahishakiye, B.M. and Ait, A.M. (2010) Valorisation de résidus de transformation industrielle de tomates: extraction et caractérisation de l'huile de graines de tomates. Mémoire Ingénieur Agronome, Spécialité Sciences, Université Saad Dahlab de Blida alimentaires, $80 \mathrm{p}$.

[30] Davies, J.N., Hobson, G.E. and McGlasson, W.B. (1981) The Constituents of Tomato Fruit-The Influence of Environment, Nutrition and Genotype. Critical Reviews in Food Science and Nutrition, 15, 205-280.

https://doi.org/10.1080/10408398109527317

[31] Korkalo, L., Hauta-alus, H. and Mutanen, M. (2011) Food Composition Tables for Mozambique. University of Helsinki, Finland.

[32] Codex Standard (2010) Norme générale codes pour les contaminants et les toxines 
présents dans les produits de consommation humaine et animale. $43 \mathrm{p}$.

[33] Karavoltsos, S., Sakellari, A., Dimopoulos, M., Dasenakis, M. and Scoullos, M. (2002) Cadmium Content in Foodstuffs from the Greek Market. Food Additives \& Contaminants, 19, 954-962.

[34] Mohamed, A.R. and Ahmed, K.S. (2006) Market Basket Survey for Some Heavy Metals in Egyptian Fruits and Vegetables. Food and Chemical Toxicology, 44, 1273 1278.

[35] Guerra, F., Trevizam, A.R., Muraoka, T., Marcante, N.C. and Caniatti-Brazaca, S.G. (2012) Heavy Metals in Vegetables and Potential Risk for Human Health. Scientia Agricola, 69, 54-60. https://doi.org/10.1590/S0103-90162012000100008

[36] Radwan, M.A. and Salama, A.K. (2006) Market Basket Survey for Some Heavy Metals in Egyptian Fruits and Vegetables. Food and Chemical Toxicology, 44, 1273 1278.

[37] Parveen, Z., Khuhro, M.I. and Rafiq, N. (2003) Market Basket Survey for Lead, Cadmium, Copper, Chromium, Nickel and Zinc in Fruits and Vegetables. Bulletin of Environmental Contamination and Toxicology, 71, 1260-1264. https://doi.org/10.1007/s00128-003-8640-4

[38] Kananke, T., Wansapala, J. and Gunaratne, A. (2014) Heavy Metal Contamination in Green Leafy Vegetables Collected from Selected Market Sites of Piliyandala Area, Colombo District, Sri Lanka. American Journal of Food Science and Technology, 2, 139-144. https://doi.org/10.12691/ajfst-2-5-1

[39] Al-Chaarani, N., El-Nakat, J., Obeid, P. and Aouad, S. (2009) Measurement of Levels of Heavy Metal Contamination in Vegetables Grown and Sold in Selected Areas in Lebanon. Jordan Journal of Chemistry, 4, 303-315.

[40] Anhwange, B.A., Kagbu, J.A., Agbaji, E.B. and Gimba, C.E.C. (2004) Trace Metal Contents of Some Common Vegetables Grown on Irrigated Farms along the Banks of River Benue within Makurdi Metropolis. Electronic Journal of Agricultural, Environmental and Food Chemistry, 5, 66-67.

[41] Robert, M. and Juste, C. (1999) Dynamique des éléments traces de l'écosystème sol. Club CRIN Environnement et Ministère de l'environnement. Spéciation des métaux dans le sol, CRIN, Paris, 495.

[42] Summut, M. (2007) Spéciation du cadmium, du plomb et du zinc dans les poussières d'émis-sions atmosphériques d'origine sidérurgique-Approche de l'impact toxicologique des poussières. Thèse, Université Paul Cézanne Aix-Marseille III, 335 p. 
Submit or recommend next manuscript to SCIRP and we will provide best service for you:

Accepting pre-submission inquiries through Email, Facebook, LinkedIn, Twitter, etc. A wide selection of journals (inclusive of 9 subjects, more than 200 journals)

Providing 24-hour high-quality service

User-friendly online submission system

Fair and swift peer-review system

Efficient typesetting and proofreading procedure

Display of the result of downloads and visits, as well as the number of cited articles Maximum dissemination of your research work

Submit your manuscript at: http://papersubmission.scirp.org/

Or contact fns@scirp.org 